\title{
Phytochemical, Pharmacognostic and Elemental Analysis of Cayratia gradis (Guill. \& Perr.) Suesseng
}

\author{
Egharevba O. Henry ${ }^{1}$, Ibrahim A. Jemilat ${ }^{{ }^{*}}$, Mustapha B. Kudirat ${ }^{2}$, Ezenwa O. Uche ${ }^{3}$, Okhale E. Samuel ${ }^{1}$ \\ ${ }^{1}$ Department of Medicinal Plant Research and Traditional Medicine, National Institute for Pharmaceutical Research and Development (NIPRD), PMB 21, \\ Garki, Abuja, Nigeria. ${ }^{2}$ Department of Medicinal Chemistry and Quality Control, National Institute for Pharmaceutical Research and Development \\ (NIPRD), PMB 21, Garki, Abuja, Nigeria. ${ }^{3}$ Department of Botany, NnamdiAzikiwe University, P.M.B, 5026. Awka, Anambra State. Nigeria.
}

\begin{tabular}{|c|c|}
\hline ARTICLE INFO & ABSTRACT \\
\hline $\begin{array}{l}\text { Article history: } \\
\text { Received on: } 09 / 04 / 2015 \\
\text { Revised on: } 22 / 04 / 2015 \\
\text { Accepted on: } 03 / 06 / 2015 \\
\text { Available online: } 27 / 07 / 2015\end{array}$ & $\begin{array}{l}\text { The plant Cayratia gracilis (Guill. \& Perr.) Sues., family Vitaceae, is renowned for its numerous medicinal } \\
\text { application in folks medicine especially for its analgesic properties. Phytochemical, physicochemical, } \\
\text { microscopic and elemental analyses were carried out on the plant to establish basic monograph information for } \\
\text { authentication of the plant samples. The moisture content was } 12.7 \% \text {, water extractive value was } 19 \% \text {, and } \\
\text { alcohol extractive value was } 3.9 \% \text { in the leaves and the moisture content of } 8.8 \% \text {, water extractive value of }\end{array}$ \\
\hline $\begin{array}{l}\text { Key words: } \\
\text { Microscopy, } \\
\text { Physicochemical, } \\
\text { Chromatograph, AAS, } \\
\text { Elemental, Standardization }\end{array}$ & $\begin{array}{l}\text { secondary metabolites for the leaves and } 6 \text { for the stem. The thin-layer chromatographic (TLC) profile of the } \\
\text { stem revealed } 4,3 \text {, and } 2 \text { spots for the hexane, ethyl acetate and methanol extracts respectively, while the leave } \\
\text { revealed 5, } 2 \text { and } 4 \text { clear spots for hexane, ethyl acetate and methanol extracts respectively. Atomic Absorption } \\
\text { Spectroscopy (AAS) of the plant shows the presence } \mathrm{Zn}, \mathrm{Cu}, \mathrm{Mn}, \mathrm{Mg}, \mathrm{Fe}, \mathrm{Na} \text {, and absence of metals like } \mathrm{Pb} \text { and } \\
\text { Cr. The study reveals microscopic characters that are useful as diagnostic parameters for Cayratia gracilis. } \\
\text { Information obtained from this study is important in establishing diagnostic indices for identification, } \\
\text { standardization, and also in monograph development of the plant which has ethno-medicinal uses. }\end{array}$ \\
\hline
\end{tabular}

\section{INTRODUCTION}

Cayratia gracilis (Guill. \& Perr.) Suesseng belongs to the family Vitaceae, It is synonymous to Cissus gracilis Guill. \& Perr. and is locally called 'Teydebedik' in Senegal, 'Basari' in Guinea, 'Kissipendekelo' in Sierra Leone, 'Dagbaniwowo' in Ghana, and 'Anaya' or 'Yaakuwarfataakke' in Hausa language of Nigeria (Burkill, 2000). It can be found in shady and damp sites of the savannah and forest region, it can be found in most African countries like Senegal, Guinea, Sierra Leone, Ghana, Nigeria, some regions of West Africa and Tropical Africa (Burkill, 2000).The Genus Cayratia comprises of about 50 different species and they are vastly distributed. Cayratia gracilis (Figure 1) is a herbaceous climber or perennial herb with opposed leaves and branched tendrils, it has slender stems of up to $7.5 \mathrm{~m}$ with

* Corresponding Author

Email: sadiqoyene@yahoo.com alternating leaves of 3-5 foliate and petiole of about $4-6 \mathrm{~cm}$ long. The leaflets are ovate or elliptical with oblong triangular stipules; it has a cuneate or cordate base and an acuminate apex (Descoings, 1972; Verdcourt, 1993).

The leaves of $C$. gracilis are occasionally eaten as vegetable in Sudan but its use as vegetable is limited elsewhere. It is considered in Senegal as a famine food that needs to be cooked together with Amorphophallus roots (Burkill, 2000).

In Tanzania, the pulped leaves are rubbed topically on slight incisions to treat lumbago. The crushed leaves mixed with Momordica foetida Schum. are used to stop the irritation caused by a spitting cobra when rubbed on the affected area (Burkill, 2000). The decoction of the leaves can be used for the relief of painful menstruation in women, its infusion can be used in the relief of child birth labour, it is said to have analgesic properties and can be used as a pain relief, it can also be used to prevent scurvy (bleeding gum) (Personal communication). The fresh roots are chewed or boiled and the decoction used as a cough remedy (Ferry, 1974). 
The leaves of $C$. gracllis as well as those of several other Asiatic species of the Genus were found to contain several flavonoids including cyanidin, delphinidin, kaempferol, myricetin and quercetin (Slamet, 2001). The aerial parts of the Cayratia gracilis is said to contain triterpene epifriedelanol, a compound with demonstrated anti-tumour activity, whereas the stem, leaves and roots contain cyanic acid (Slamet, 2001).
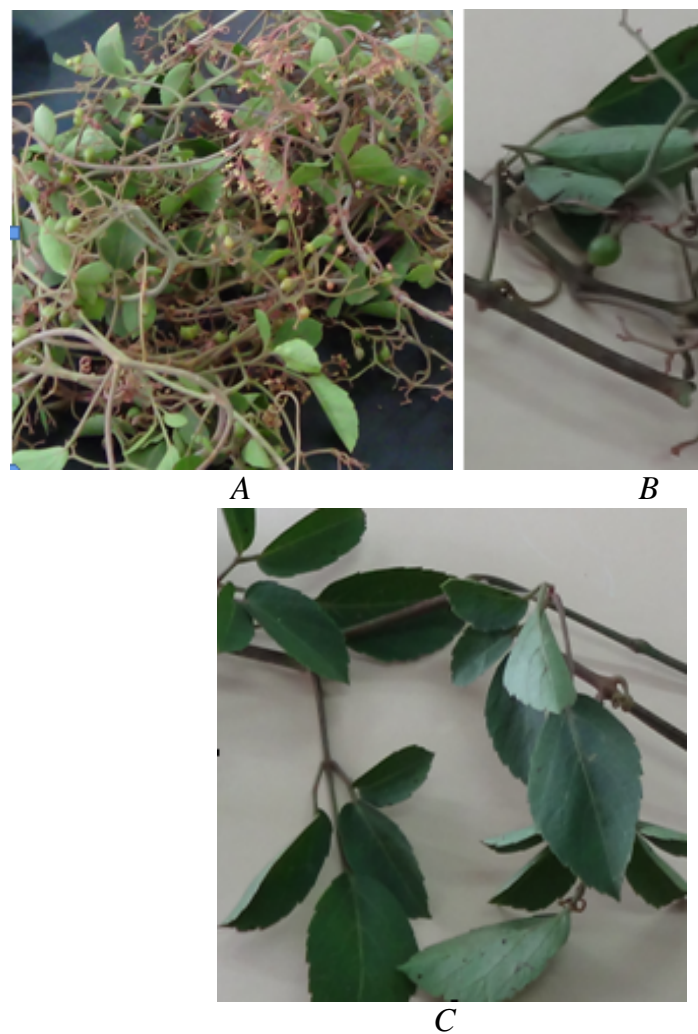

Fig. 1: Pictures of Cayratia gracilis (A: whole plant; B: fruits; C: leaves)

The medicinal plant, $C$. gracilis like other plants is very sensitive and easily and variously affected by environmental and edaphic factors (Saber, 1975). Any change in any of these factors depreciates its medicinal potentials or lose its activities (OAU/STRC, 1979). Not only its age but stage of development, time of collection are of great importance as to its value as an agent of therapy (Saber, 1975). Information on the mineral content, phytochemistry and pharmacological properties of Cayratia gracilis is limited.

In view of its use as a vegetable and many medicinal uses, as well as results from related Asiatic species, this work is aimed at finding the phytochemical constituents, microscopy, pharmacognostic and elemental composition of the leaf and stem of $C$. gracilis found in Abuja, Nigeria.

\section{MATERIALS AND METHOD}

\section{Collection of plant}

The Cayratia gracilis plant was collected from Idu Industrial area, Abuja, Nigeria in July, 2013. The plant was identified in the herbarium of the National Institute for
Pharmaceutical Research and Development, Abuja, Nigeria by a Taxonomist.

\section{Plant sample processing}

The fresh leaves and stem was air dried indoors for about 8-9 days. The leaves and stem was powdered using mortar and pestle, but later blended with electronic blending machine. The powdered samples were stored in air tight containers for the phytochemical analysis.

\section{Microscopic examination}

Leaves of Cayratia gracilis was cut at the median portion. Some of it was soaked in concentrated nitric acid and some in sodium hypochlorite and left for about 48hours. The appearance of air bubbles showed that the epidermis was ready to be separated.

The sample was then transferred to petri dishes containing water and with the use of fine forceps and dissecting needle; the upper and lower epidermis was separated. Each sample was stained with saffranin and sudan IV and then mounted on slides in glycerol. The edges of the cover slip were sealed with nail varnish to prevent dehydration.

\section{Determination of Physicochemical constants}

Determination of the moisture content and extractive values of the powdered leaves and stem were carried out according to standard methods (Sofowora, 2008; Evans, 2002; African pharmacopeia, 1986).

\section{Phytochemical analysis}

The powdered leaves and stem were screened for the presence of secondary metabolite such as carbohydrate, tannins, saponins, anthraquinones, flavonoids, alkaloids, terpenes, resins, balsam, and sterols. The phyto-chemical screening were carried out following standard methods (Sofowora, 2008; Evans, 2002)

\section{Thin-layer chromatography}

Thin layer chromatography (TLC) of the extracts was carried out to determine the number of components present in each extract. TLC plates pre-coated with $\mathrm{K}_{5}$ silica gel were used. Spotting was done using capillary tubes. The hexane and ethyl acetate extracts were developed in a solvent system of hexane/ethyl acetate, ratio 9:1, while the methanol extract was developed in a solvent system of ethyl-acetate and methanol in ratio 3:2. The plates were sprayed with dilute sulphuric acid, heated in an oven for $3 \mathrm{~min}$ at $110^{\circ} \mathrm{C}$ and observed for spots after (Evans, 1996) and the retardation factor $\left(\mathrm{R}_{\mathrm{f}}\right)$ for each spot was determined.

\section{Elemental Analysis}

Elements such as Zinc $(\mathrm{Zn})$, Copper $(\mathrm{Cu})$, Manganese $(\mathrm{Mn})$, Magnesium $(\mathrm{Mg})$, Iron $(\mathrm{Fe})$, Sodium $(\mathrm{Na})$, Lead $(\mathrm{Pb})$ and Chromium (Cr) were assessed qualitatively and quantitatively 
using the method of Association of Official Analytical Chemist (AOAC, 1980) with the aid of Atomic Absorption Spectrometer (AAS) (GBC AVANTA Model) using hollow cathode lamp of the elements and a fuel rich flame (air-acetylene). Standards and digested samples were aspirated and the mean signal responses were recorded at each of the elements respective wavelengths.

\section{RESULTS AND DISCUSSION}

\section{Microscopic examination}

Figure 2 shows the photomicrograph of the upper epidermal layers of the leaves of Cayratia gracilis with the polygonal shaped cells of the upper surface, spindle shaped crystals of calcium oxalate, glandular trichomes with striated base, prism crystals of oxalate, and the anomocytic stomata.

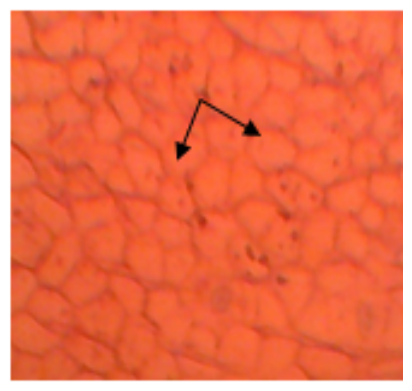

A

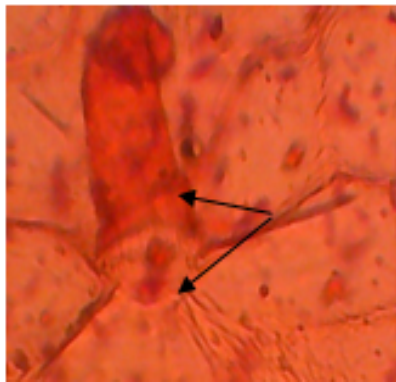

C

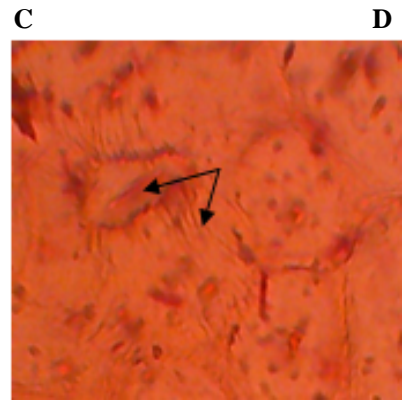

Fig. 2: Photomicrographs of upper epidermal layer of Cayratia gracilis leaf.

Key: A: Polygonal shaped cells B: Spindle shaped crystals C: Glandular trichomes with striated base D: Prismatic crystals E: Anomocytic stomata with striated surrounding base

The lower epidermal layer of Cayratia gracilis showed polygonal shaped cells, highly striated cells obstructing the epidermal cells, scattered spindle shaped crystals, anenocytic stomata with striations, multicellular glandular trichomes which are more concentrated towards the venations (Figure 3 ).

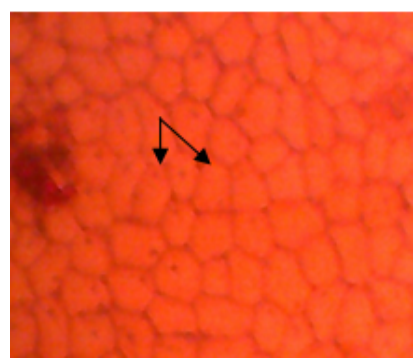

I

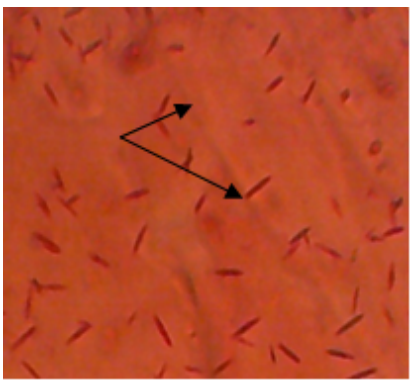

III

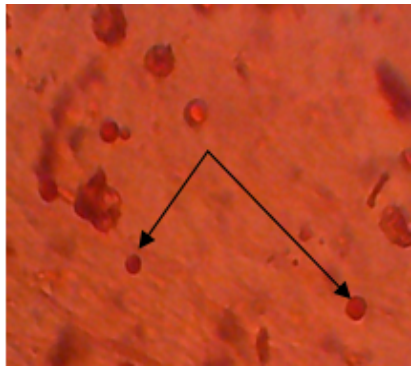

V

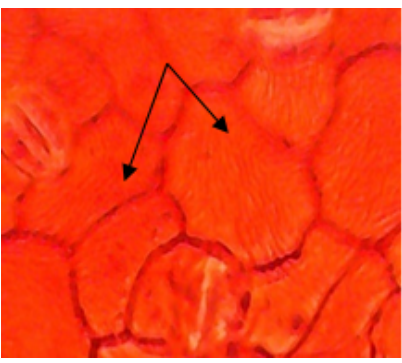

II

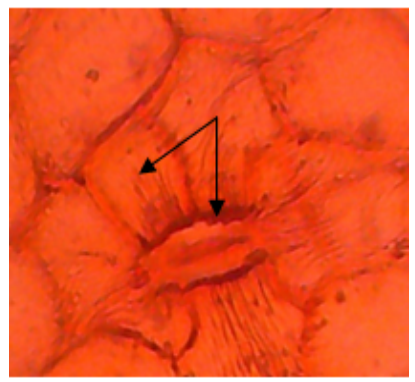

IV

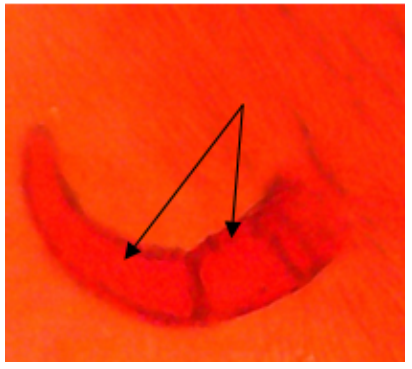

Fig. 3: Photomicrograph of lower epidermal layer of Cayratia gracilis leaf. Key: i: polygonal shaped cells, ii: highly striated cells obstructing the epidermal cells, iii: Scattered spindle shaped crystals, iv: anenocytic stomata with striations, v: Oil globules, vi: multicellular glandular trichomes which are more concentrated towards the venations.

Epidermal characteristics observed, such as, striations on the epidermal cells, abundance of multi-cellular trichomes, prismatic and spindle shaped crystals, anomocytic stomata cell shapes, etc., can also be used as diagnostic features for the authentication of the plant samples.

\section{Physicochemical parameters}

Table 1 shows the results of the physicochemical parameters of the leaf and stem of $C$. gracilis. The qualitative evaluation of the leaf and stem sample showed the alcohol extractive values to be $3.9 \%$ and $1.3 \%$ respectively and the water extractive values to be $19 \%$ and $14.8 \%$ respectively.

This suggests that water is the best extractive solvent for the plant materials. The values of the moisture content of the leaf and stem $(12.7 \%$ and $8.8 \%)$ were between the official ranges of 8-14.5 for vegetable drugs (African pharmacopeia, 1989). This implied that the plant does not retain much water to support microbial attack after drying and when stored under good condition. This may have good implication on the shelf-life of the well-packaged crude vegetable drug. 
Table 1: Result of the physicochemical parameters of the leaves and stem of $C$. gracilis.

\begin{tabular}{ccc}
\hline Parameter & $\begin{array}{c}\text { C. gracilis leaves } \\
(\boldsymbol{\%})\end{array}$ & C. gracilis stem (\%) \\
\hline Moisture content & 12.7 & 8.8 \\
Alcohol extractive value & 3.9 & 1.3 \\
Water extractive value & 19 & 14.8 \\
\hline
\end{tabular}

\section{Phytochemical Screening}

The result of phytochemical screening is shown in Table

2. The results revealed the presence of several metabolites in the leaf and stem of Cayratia gracilis. The metabolites present for the leaves were carbohydrate, tannins, saponins, flavonoids, Balsams, Resins, alkaloids and sterols while those present in the stem include carbohydrate, saponins, flavonoids, terpenes, balsams, resins and alkaloids. The usefulness of these metabolites in phytomedicines or treatment of ailment has been well documented. Tannins have astringent and anti-diarrhoea activity, and also used for treatment of sexually transmitted diseases. Saponins are used for the treatment of gastro-intestinal infections and cardiovascular diseases. The activity of flavonoids as free radical scavengers has been established and are being exploited in the management of inflammatory diseases such as tumour, and in oxidative stress related diseases (Robertson and Heber, 1956; Haslem, 1989; Evans, 2002). Therefore, the presence of these metabolites in these plants supports their uses in treatment of various ailments traditionally (Burkil, 2000).

Table 2: Result of the phytochemical analysis of the leaves and stem of Cayratia gracilis.

\begin{tabular}{lcc}
\hline Secondary metabolite & Leaves & Stem \\
\hline Carbohydrate & + & + \\
Tannins & + & - \\
Saponins & + & + \\
Flavonoids & + & + \\
Anthraquinones & - & - \\
Terpenes & - & + \\
Balsams & + & + \\
Resins & + & + \\
Alkaloids & + & + \\
Sterols & + & - \\
Key: + Detected; & - = Not detected
\end{tabular}

\section{Thin Layer Chromatography (TLC)}

The results of TLC of the leaf and stem extracts are as shown in table 3 . The hexane and ethyl acetate extracts gave 5 and 4 spots and 2 and 3 spots for the leaf and stem respectively, while the methanol extract for the leaf and stem gave 4 and 1 spots.

Table 3: Results of TLC analysis of the extracts of the leaf and stem of Cayratia gracilis.

\begin{tabular}{|c|c|c|c|c|c|c|}
\hline \multirow[t]{2}{*}{ Spots } & \multicolumn{2}{|c|}{$\begin{array}{c}\text { Hexane extract } \\
\left(\mathbf{R}_{\mathbf{f}}\right)\end{array}$} & \multicolumn{2}{|c|}{$\begin{array}{l}\text { Ethyl acetate } \\
\text { extract }\left(R_{f}\right)\end{array}$} & \multicolumn{2}{|c|}{$\begin{array}{c}\text { Methanol } \\
\text { Extract }\left(\mathbf{R}_{\mathbf{f}}\right)\end{array}$} \\
\hline & Leaf & Stem & Leaf & Stem & Leaf & Stem \\
\hline 1 & 0.05 & 0.06 & 0.76 & 0.63 & 0.09 & 0.96 \\
\hline 2 & 0.09 & 0.08 & 0.98 & 0.72 & 0.24 & \\
\hline 3 & 0.14 & 0.15 & & 0.96 & 0.74 & \\
\hline 4 & 0.21 & 1.00 & & & 0.96 & \\
\hline 5 & 0.30 & & & & & \\
\hline
\end{tabular}

The TLC fingerprinting is indicative of the presence of secondary metabolites on the plant and can be used to identify, standardize and differentiate between the plant species and other species of the same Genus.

\section{Elemental Analysis}

The result of elemental analysis is show in Table 4 . Seven essential metals were screened but two of the metals, $(\mathrm{Pb}$ and $\mathrm{Cr}$ ) were not detected while five $(\mathrm{Mg}, \mathrm{Zn}, \mathrm{Fe}, \mathrm{Cu}, \mathrm{Na}$ and $\mathrm{Mn}$ ) were detected and quantified. $\mathrm{Zn}, \mathrm{Fe}, \mathrm{Mn}, \mathrm{Mg}$ and $\mathrm{Cu}$ are essential metals which play important role in various cellular metabolic processes, including normal growth and development, including the development of the brain. Some of these metals enable the body to utilize vitamins ( $\mathrm{C}, \mathrm{B}$, biotin etc.) and neutralize free radical, prevent diabetes, enhance growth of connective tissues and help in blood formations.

The dietary limits of $\mathrm{Zn}, \mathrm{Fe}$ and $\mathrm{Mn}$ are $100 \mu \mathrm{g} / \mathrm{g}, 10$ $60 \mathrm{mg} /$ day and $11 \mu \mathrm{g} / \mathrm{g}$ respectively, according to WHO (1998) and Kaplan et. al., (1993). The deficiency of these essential metals may results in loss of sense of touch, smell (Hunt, 1994), gastrointestinal infections, nose bleeding (Hunt, 1994) birth defects and reduced fertility. All the metal analyzed were within WHO permissible limits and may not result in any health hazards to consumers since Cayratia gracilis is eaten as food, and it is also encouraging that the plant is $\mathrm{Pb}$ and $\mathrm{Cr}$ free.

Table 4: Elemental Analysis Result of leaves of Cayratia gracilis.

\begin{tabular}{lllllllll}
\hline Elements & $\mathbf{P b}$ & $\mathbf{C r}$ & $\mathbf{Z n}$ & $\mathbf{C u}$ & $\mathbf{M n}$ & $\mathbf{F e}$ & $\mathbf{N a}$ & $\mathbf{M g}$ \\
\hline Inferences & - & - & + & + & + & + & + & + \\
\hline Quantity & 0.00 & 0.00 & 26.5 & 3.30 & 44.25 & 37.95 & 77.15 & 326 \\
$(\mu \mathrm{g} / \mathrm{g})$ & & & & & & & & .50 \\
\hline
\end{tabular}

Key: - means not detected, + means detected.

\section{CONCLUSION}

Cayrtia gracilis is rich in secondary metabolites and can be a potential source of phyto-medicines and leads for new drugs. The diagnostic characters generated from this study will be useful in identification and the results will also be useful in standardization towards quality assurance and in preparation of monograph on the plant. We recommend that further studies should be carried out to verify the claimed traditional uses of the plant.

\section{AKNOWLEDGEMENT}

The authors wish to acknowledge the contribution of Mall. Muazzam Ibrahim of Herbarium and Ethnobotany Unit, in collection of the plant material used for the study.

\section{REFERENCES}

African Pharmacopoeia. 1986. General Methods of Analysis. Lagos, OAU/STRC. 143.

AOAC. 1980. Official Methods of Analysis $12^{\text {th }}$ Edn. Horwitz W. Ed. Association of Official Chemists. Washington DC. 1015

Burkill HM. 2000. The useful plants of West Tropical Africa. $2^{\text {nd }}$ ed. Vol. 5. Families S-Z. Royal Botanic Gardens. Kew. UK. 686. 
Descoings B. 1972. Vitaceae. Flore du Cameroun. Volume 13. Muséum National d'Histoire Naturelle, Paris, France. 1132

Evans WC. 2002. Trease and Evans Pharmacognosy, $15^{\text {th }}$ Ed. London: W.B. Sanders. 183-393.

Evans WC. 1996. Trease and Evans Pharmacognosy. 14th edition. W.B. Saunder Company Ltd. London. 105-108; 545-578

Ferry MP, Gessain M, Gessain R. 1974. Ethnobotanique Tenda. Docums. Center Rech. Anthrop. Mus. Homme. No; Paris. 307

Haslem E. 1989. Plant polyphenols: Vegetable tannins revisited - chemistry and pharmacology of natural products. Cambridge University Press, Cambridge. 169.

Hunt JR. Bioavailability of Fe, Zn, and other trace minerals for Vegetarian Diets. Am. J. Clin. Nutr. 1994; 78:633-39

Kaplan L A, Peace AJ, Kazomierczak SC .1993. Theory Analysis Correlation. In Clinical Chemistry $4{ }^{\text {th }}$ Edn, Mosby. 707

Kokwaro JO. 1993. Medicinal plants of East Africa. $2^{\text {nd }}$ Edition. Kenya Literature Bureau, Nairobi, Kenya. 401.

OAU/STRC. 1979. 4th Inter-African Symposium on Traditional Pharmacopeia and African Medicinal Plants: Abidjan-Ivory Coast. OAU/STRC. 743.

Robertson P, Herber WY. 1995. Pharmacognosy. J.B Lippincott Company. 123-125.
Slamet SBR.2001. Cissus AHL. Juss. In: van Valkenburg, JLCH \& Bunyapraphatsara, N (Eds) Pla.nt Resources of South-East Asia No 12(2): Medicinal and poisonous plants 2. Backhuys Publishers, Leiden, Netherlands. 144-147.

Sofowora A. 2008. Medicinal Plants and Traditional Medicine in Africa. ${ }^{\text {rd }}$ Ed. Ibadan, Nigeria: Spectrum Books Limited. $199-204$.

Verdcourt B. 1993. Vitaceae. In: Polhill, R.M. (Editor). Flora of Tropical East Africa. AA. Balkema, Rotterdam, Netherlands. 149.

WHO. 1998. Quality control methods for medicinal plants materials. WHO Geneva, Switzerland, Materials. 128

\section{How to cite this article:}

Henry O. Egharevba, Jemilat A. Ibrahim, Kudirat B. Mustapha, Uche O. Ezenwa, Samuel E. Okhale. Phytochemical, Pharmacognostic and Elemental Analysis of Cayratia gracilis (Guill. \& Perr.) Suesseng. J App Pharm Sci, 2015; 5 (07): 048-052. 